\title{
Fluorescent Glyconanoparticles as a Sensitive Device to Monitor Sugar-Involving Molecular Events
}

\author{
Kenichi Nitkura, ${ }^{*}$ Noriko Osuga, ${ }^{* *}$ Noriko Nagahori, ${ }^{* * *}$ Reiko Sadamoto, ${ }^{* * *}$ Masamichi Shiono, ${ }^{* * *}$ \\ Norimasa IwASAKI, ${ }^{* *}$ Kenji Monde, ${ }^{*}$ Akio MinAmI, ${ }^{* *}$ and Shin-Ichiro NishimURA, ${ }^{* * * * *, \dagger}$ \\ *Division of Biological Sciences, Graduate School of Science, Frontier Research Center for Post-Genomic Science and Technology, \\ Hokkaido University, Kita 21, Nishi 11, Kita-ku, Sapporo 001-0021, Japan \\ ** Graduate School of Medicine, Hokkaido University \\ *** Japan Bioindustry Association, Sapporo 001-0021, Japan \\ ****National Institute of Advanced Industrial Science and Technology (AIST), Sapporo 062-8517, Japan
}

(Received October 1, 2003; Accepted January 9, 2004)

\begin{abstract}
We prepared sugar-displayed fluorescent nanoparticles using photopolymerization of the vesicles of diacetylene-containing glycolipids. After photopolymerization, the nanoparticles exhibited fluorescent emission at 400$600 \mathrm{~nm}$ upon excitation at $380 \mathrm{~nm}$. The binding of sugar-recognizing proteins (lectins) onto the fluorecent nanoparticles induced changes in fluorescence. The fluorescent intensity of the nanoparticles decreased with an increase in lectin concentration. On the contrary, the enzymatic release of oligosaccharides from the glyconanoparticles gave an increase in fluorescence. Using a phosphatidylcholine-type lipid as the matrix lipid of the nanoparticles, the non-specific adsorption of lectins on the surface was drastically restricted, leading to the generation of a specific response to the target proteins. KEY WORDS Glyconanoparticle / Lectin / sLeX / Carbohydrate-Protein Interaction /
\end{abstract}

Living cells and almost all proteins are covered with carbohydrates. Carbohydrates on the cell surface often act as ligands for a variety of extracellular proteins. Therefore, a sensing technique for carbohydrate-involving events has been an important theme in the fields of biology and biotechnology. Surface plasmon resonance (SPR) ${ }^{1}$ and quartz crystal microbalance $(\mathrm{QCM})^{2}$ have been found to be reliable methods for detecting these molecular recognitions. However, such methods require special and expensive apparatus for the sensing. A simple coloriometric sensing system, inspired by molecular recognitions on the cell surface, has been firstly developed by Charych et al. using polydiacetylene vesicles incorporating naturally occurring glycolipids. ${ }^{3,4}$ The conjugated ene-yne backbone of 10,12-pentacosadilynoic acid (PDA 1)-based polydiacetylene vesicles results in a colored solution (Scheme 1). They reported that the color of the vesicules was changed before and after the binding of relatively large ligands, such as cholera toxin and influenza virus, to the carbohydrate on the vesicular surface. This method was also applied to the detection of bacteria. ${ }^{5}$

In this paper, we report glycolipid-based polymerized vesicles (hereafter referred to as nanoparticles) as fluorescent-sensing material for the detection of sugar-protein interactions (Figure 1). We expected sugar-displayed fluorescent nanoparticles to sense the binding of ligands too small to be detected using the conventional coloriometric method since fluores- cent detection is generally more sensitive than coloriometric detection. Instead of PDA as a matrix lipid as in Charych's system, when diacetylene-containing phosphatidylcholine derivative $\mathbf{3}$ was used for the copolymerization as a matrix lipid with glycolipid monomers, the nanoparticles generated relatively strong fluorescence after UV irradiation. The degree of the cross-linkage of the nanoparticle surface was controlled by alternating the photo-irradiation period or adding non-polymerizable lipids to the nanoparticle. The fluorescent response upon binding lectins onto the nanoparticles was evaluated. We also tested the effect of the enzymatic release of oligosaccharides on fluorescent intensities. Here, we report a facile and effective synthetic strategy to construct diacetylenecontaining glycolipids by a simple chemical ligation of free carbohydrates with hydroxylamine-attached lipids.

\section{EXPERIMENTAL}

10,12-tricosadiynoyl containing phospholipid 3 was purchased from Avanti Polar Lipid, Inc. USA. Winged bean lectin was purchased from Sigma. Fluorescence spectra were measured with an F-2500 spectrophotometer (Hitachi, Ltd., Japan).

\section{Synthesis of Diacetylene-containing Lactose Lipid 4 \\ L-Serineoctadecylamide $7 . \quad 10 \% \mathrm{Pd}-\mathrm{C}(200 \mathrm{mg})$ was added to a solution of $N$-Benzyloxycarbonyl-L-}

${ }^{\dagger}$ To whom correspondence should be addressed (Tel: +81-11-706-9043, Fax: +81-11-706-9042, E-mail: shin@ glyco.sci.hokudai.ac.jp). 

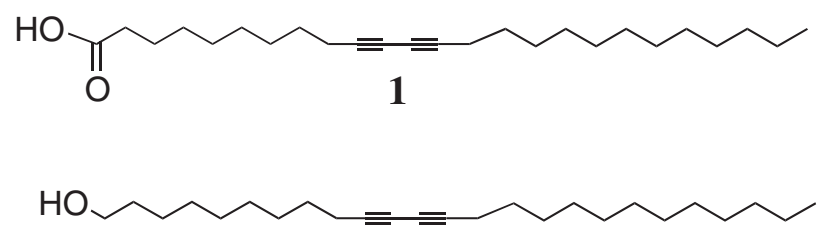

2

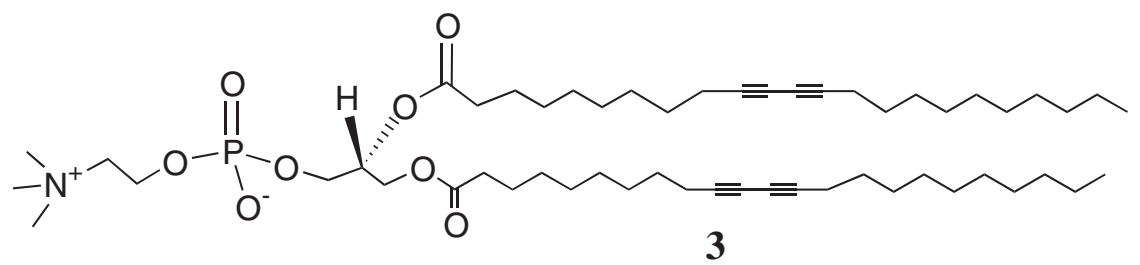

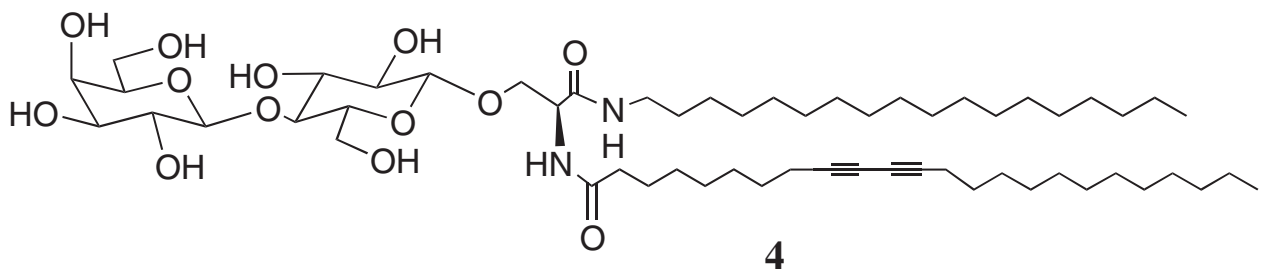

Scheme 1. Chemical structure of photopolymerizable lipids.

\section{No fluorescence}

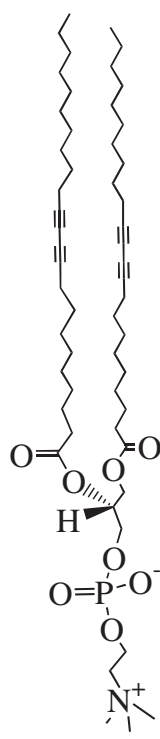

Fluorescence
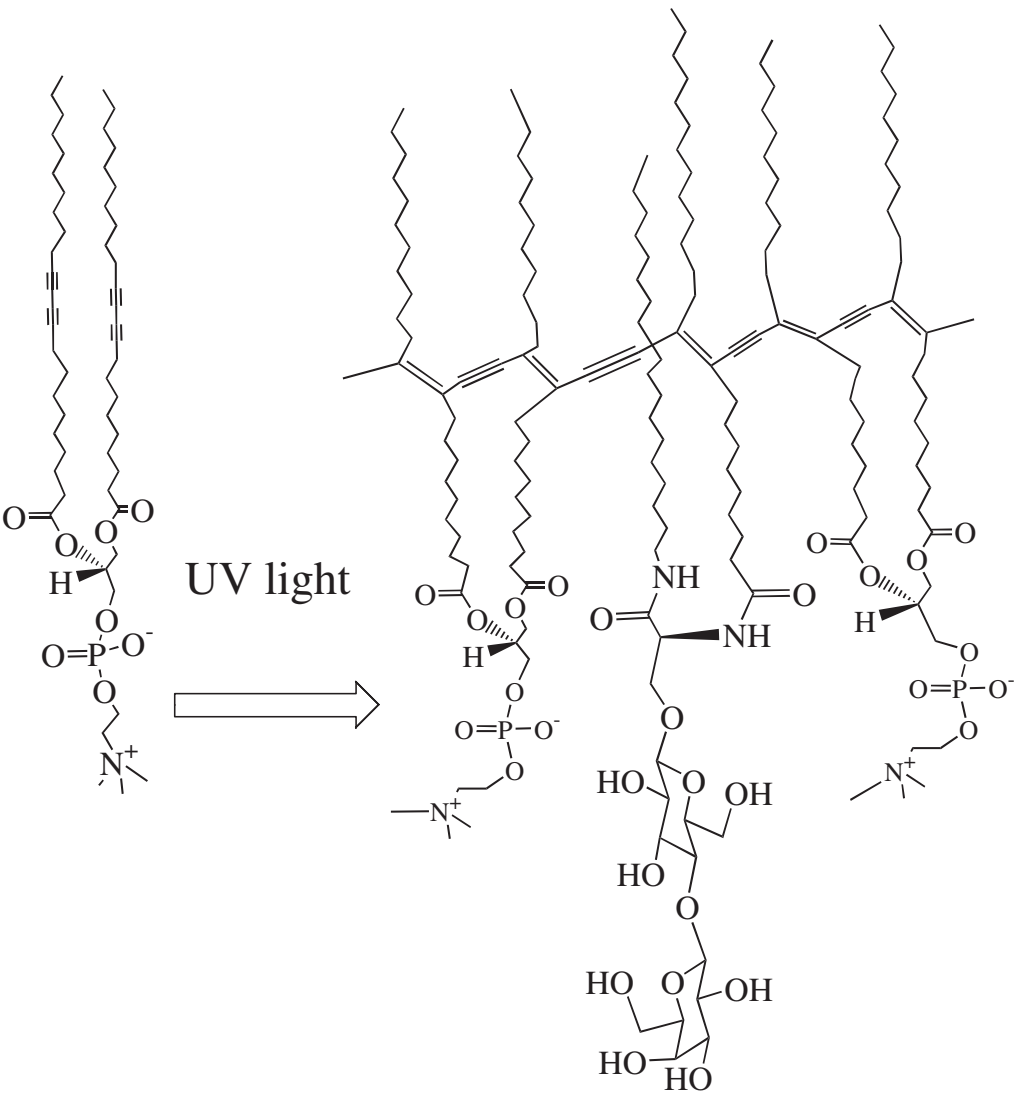

Figure 1. Photopolymerization of diacetylene-containing glycolipids at the surface of vesicle by UV irradiation.

serineoctadecylamide $6(6.7 \mathrm{~g}, 13.7 \mathrm{mmol})$ in $1: 1$ methanol/chloroform $(140 \mathrm{~mL})$. The reaction mixture was stirred for $45 \mathrm{~h}$ at $25^{\circ} \mathrm{C}$ under a hydrogen atmosphere $(0.32 \mathrm{Mpa})$. The solvent was filtrated and evapo- rated under reduced pressure: ${ }^{1} \mathrm{HNMR}\left(\mathrm{CDCl}_{3}\right): \delta$ $5.12(\mathrm{~s}, 1 \mathrm{H}, \mathrm{NH}), 3.92\left(\mathrm{~m}, 1 \mathrm{H}, \mathrm{NH}_{2} \mathrm{CHCO}\right), 3.24$ $\left(\mathrm{m}, 2 \mathrm{H}, \mathrm{NH}_{2}\right), 1.53\left(\mathrm{~m}, 2 \mathrm{H}, \mathrm{NHCH}_{2}\right), 1.27(\mathrm{~m}, 30 \mathrm{H}$, $\left.\mathrm{CH}_{2}\right), 0.89$ (t, 3H, $\mathrm{CH}_{3}$ ). TOF MS $m / z 357.85[\mathrm{M}+$ 
$\mathrm{H}]^{+}$(Calcd. for $\mathrm{C}_{21} \mathrm{H}_{45} \mathrm{~N}_{2} \mathrm{O}_{2}{ }^{+}$: 357.35).

$N$-(Benzophenone)-L-serineoctadecylamide 8. L-Serineoctadecylamide 7 was added to a solution of benzophenone imime $(5.62 \mathrm{~g}, 31.0 \mathrm{mmol})$ and camphor-10-sulfonic acid $(771.40 \mathrm{mg}, 3.32 \mathrm{mmol})$ in $1: 1$ methanol/dichlometane $(300 \mathrm{~mL})$ at $0{ }^{\circ} \mathrm{C}$. The reaction mixture was warmed to room temperature and stirred for $40 \mathrm{~h}$. The solvent was evaporated under reduced pressure, and washed with saturated sodium hydrogen carbonate and brine, and dried over magnesium sulfate. The mixture was filtrated and concentrated. Then the residue was chromatographed on silica gel with $2: 10.5 \%$ triethylamine hexane/ethylacetate ( $0.5 \%$ triethylamine) as eluent to give $8(4.42 \mathrm{~g}$, $62 \%):{ }^{1} \mathrm{H} \mathrm{NMR}\left(\mathrm{CDCl}_{3}\right): \delta 7.66-7.13\left(\mathrm{~m}, 10 \mathrm{H}, \mathrm{Ph}_{2}\right)$, $4.11(\mathrm{~m}, 1 \mathrm{H}) 3.98(\mathrm{~m}, 1 \mathrm{H}), 3.86(\mathrm{~m}, 1 \mathrm{H}), 1.35-0.98$ (m, 30H, $\mathrm{CH}_{2}$ ), 0.88 (t, 3H, $\mathrm{CH}_{3}$ ). TOF MS $m / z 521.7$ $[\mathrm{M}+\mathrm{H}]^{+}$(Calcd. for $\mathrm{C}_{34} \mathrm{H}_{52} \mathrm{~N}_{2} \mathrm{O}_{2}:$ 521.40).

$O$-(4-O-2,3,4,6-Tetra-O-acetyl- $\beta$-D-galactopyranosyl)-(1-4)-O-[2,3,4,6-tetra-O-acetyl-D-glucopyranosyl]-N-(benzophenone)-L-serineoctadecylamide 10.

Trifluoromethanesulfonic acid $(75 \mu \mathrm{L}, 0.845 \mathrm{mmol})$ was added to a suspension of $O$-(4-O-2,3,4,6,-tetra$O$-acetyl- $\beta$-D-galactopyranosyl)-(1-4)-O-2,3,4,6-tetra$O$-acetyl-D-glucopyranosyl-thiophenol $9(501.36 \mathrm{mg}$, $0.69 \mathrm{mmol})$ and $\mathbf{8}(295.53 \mathrm{mg}, 0.83 \mathrm{mmol})$, and molecular sieves $4 \AA$ in dichloromethane at $0{ }^{\circ} \mathrm{C}$ under a nitrogen atmosphere. The reaction mixture was warmed to room temperature and stirred for $15 \mathrm{~h}$. The mixture was filtrated through celite. The filtrate was washed with $10 \%$ sodium thiosulfate and saturated sodium hydrogen carbonate and brine, and dried over magnesium sulfate. The mixture was filtrated and concentrated. Then the residue was chromatographed on silica gel with 1:1 hexane/ethylacetate as an eluent to give 10 (743.5 mg, 94.8\%): ${ }^{1} \mathrm{HNMR}\left(\mathrm{CDCl}_{3}\right): \delta 7.66(\mathrm{~d}$, $2 \mathrm{H}, \mathrm{Ph}), 7.45-7.36,(\mathrm{~m}, 6 \mathrm{H}, \mathrm{Ph}), 7.12(\mathrm{~d}, 2 \mathrm{H}, \mathrm{Ph})$, $6.73\left(\right.$ br s, $\left.1 \mathrm{H}, \mathrm{NH}_{\text {ser }}\right), 5.32(\mathrm{~d}, 1 \mathrm{H}, \mathrm{H}-4), 5.12(\mathrm{t}, \mathrm{J}$ $9.00,9.06 \mathrm{~Hz}, 1 \mathrm{H}, \mathrm{H}-3), 5.08(\mathrm{t}, \mathrm{J} 9.00,9.12 \mathrm{~Hz}, 1 \mathrm{H}$, $\mathrm{H}-2), 4.93(\mathrm{dd}, 1 \mathrm{H}, \mathrm{H}-3), 4.87$ (t, J 8.28, $8.34 \mathrm{~Hz}$, 1H, H-2), 4.45 (d, J $7.44 \mathrm{~Hz}, 1 \mathrm{H}, \mathrm{H}-1), 4.41(\mathrm{~d}, \mathrm{~J}$ $7.92 \mathrm{~Hz}, 1 \mathrm{H}, \mathrm{H}-1), 4.37$ (d, J $11.82 \mathrm{~Hz}, 1 \mathrm{H}, \mathrm{H}-6 \mathrm{~b})$, 4.08-4.03 (m, 3H, H-6a, H-6ab), 3.81-3.76 (m, J $6.72,6.54,9.36 \mathrm{~Hz}, 2 \mathrm{H}, \mathrm{H}-4$ and $\mathrm{H}-5), 3.51(\mathrm{~m}, 1 \mathrm{H}$, $\mathrm{H}-5), 3.27\left(\mathrm{~m}, 2 \mathrm{H},-\mathrm{OCH}_{2}\right), 2.17-1.93(6 \mathrm{~s}, 21 \mathrm{H}$, 7OAc), $1.26\left(\mathrm{~m}, 34 \mathrm{H}, 17 \mathrm{CH}_{2}\right), 0.88\left(\mathrm{t}, 3 \mathrm{H}, \mathrm{CH}_{3}\right)$. TOF MS $m / z 1138.58$ [M] (Calcd. for $\mathrm{C}_{60} \mathrm{H}_{86} \mathrm{~N}_{2} \mathrm{O}_{19}$ : 1138.58).

$\beta$-D-Lactopyranosyl-N-(benzophenone)-L-serineoctadecylamide 11. Sodium methoxide $(3.36 \mathrm{mg}$, $0.06 \mathrm{mmol}$ ) was added to a solution of compound $\mathbf{1 0}$ $(235.5 \mathrm{mg}, 0.21 \mathrm{mmol})$ in dry methanol $(50 \mathrm{~mL})$ and the mixture was stirred for $4 \mathrm{~h}$ at room temperature. The solution was neutralized with Amberlite IR-120 resin, filtered and concentrated: TOF MS $m / z$
868.19 $[\mathrm{M}+\mathrm{Na}]^{+}$(Calcd. for $\mathrm{C}_{46} \mathrm{H}_{72} \mathrm{~N}_{2} \mathrm{O}_{12} \mathrm{Na}^{+}$: 867.50).

$\beta$-D-Lactopyranosyl-L-serineoctadecylamide 12. $\mathrm{Pd}-\mathrm{C}(48 \mathrm{mg})$ was added to the residue in methanol $(80 \mathrm{~mL})$ and stirred for $15 \mathrm{~h}$ at room temperature under a hydrogen atmosphere. The mixture was filtrated through celite and concentrated to generate 4: TOF MS $m / z$ 681.4 $[\mathrm{M}+\mathrm{H}]^{+}$(Calcd. for $\mathrm{C}_{33} \mathrm{H}_{65} \mathrm{~N}_{2} \mathrm{O}_{12}{ }^{+}$: 681.45).

$N$-(10,12-Pentacosadiynoyl)-O- $\beta$-D-lactopyranosylL-serineoctadecylamide 4. 1-Ethyl-3-(3-dimethylaminopropyl) carbodiimide hydrochloride (EDC) (140 mg, $0.73 \mathrm{mmol}$ ) and 10,12-pentacosadiynoic acid (165 mg, $0.44 \mathrm{mmol}$ ) were added to a solution of $\mathbf{1 2}$ (140.7 $\mathrm{mg}, 0.21 \mathrm{mmol}$ ) and $N$-ethyldiisopropylamine $(12.8 \mathrm{mg}, 0.10 \mathrm{mmol})$ in dry methanol $(50 \mathrm{~mL})$ and chloroform $(10 \mathrm{ml})$. The mixture was stirred for $18 \mathrm{~h}$ at room temperature. The solvent was evaporated and chromatographed on silica gel, eluted with 10:1-6:1 v/v chloroform/methanol to afford pure 4 (90.2 $\mathrm{mg}, 42 \%)$ as a white solid; ${ }^{1} \mathrm{HNMR}\left(\mathrm{CD}_{3} \mathrm{OD} /\right.$ $\left.\mathrm{CDCl}_{3}=1: 1\right): \delta 4.34(\mathrm{~d}, 1 \mathrm{H}, \mathrm{H}-1, J=7.8 \mathrm{~Hz})$, $4.29(\mathrm{~d}, 1 \mathrm{H}, \mathrm{H}-1, J=7.75 \mathrm{~Hz}), 4.15(\mathrm{dd}, 1 \mathrm{H}$, $\left.-\mathrm{OCH}_{2} \mathrm{CHNH}\right), 3.30(\mathrm{t}, 1 \mathrm{H}, \mathrm{H}-2, J=8.05,8.8 \mathrm{~Hz}$ ), $3.20\left(\mathrm{t}, 2 \mathrm{H}, \mathrm{CH}_{2} \mathrm{NH}\right), 2.26-2.24(\mathrm{~m}, 6 \mathrm{H}), 0.88(\mathrm{t}$, $\left.6 \mathrm{H}, \mathrm{CH}_{3}\right) .{ }^{13} \mathrm{C} \mathrm{NMR}\left(\mathrm{CDCl}_{3}\right): \delta 177.6(\mathrm{NHCO})$, 173.2 (NHCO), 106.7 (C-1), 106.0 (C-1), 82.7, 80.5, $80.3,80.0,78.5,74.1,52.0,51.8,51.6,51.5,51.3$, 51.1, 50.9, $34.7\left(\mathrm{CH}_{2}\right), 32.5\left(\mathrm{CH}_{2}\right), 32.4\left(\mathrm{CH}_{2}\right), 32.3$ $\left(\mathrm{CH}_{2}\right), 32.1\left(\mathrm{CH}_{2}\right), 32.0\left(\mathrm{CH}_{2}\right), 31.9\left(\mathrm{CH}_{2}\right), 31.6$ $\left(\mathrm{CH}_{2}\right), \quad 31.1\left(\mathrm{CH}_{2}\right), 25.5\left(\mathrm{CH}_{2} \mathrm{CH}_{3}\right), 21.9,16.7$ $\left(\mathrm{CH}_{3}\right)$. ESI-MS $\mathrm{m} / \mathrm{z} 1035.9[\mathrm{M}-\mathrm{H}]^{-}$(Calcd. for $\mathrm{C}_{58} \mathrm{H}_{103} \mathrm{~N}_{2} \mathrm{O}_{13}$ : 1035.75).

\section{General Procedure for Chemoselective Ligation}

Hydroxylamine-attached lipid 3 (5 mg, $9.1 \mu \mathrm{mol})$ and carbohydrates, $\mathbf{a}$ or $\mathbf{b}(1-5 \mathrm{mg})$, were mixed in methanol $(0.7 \mathrm{~mL})$ at room temperature. The mixture was stirred for $24 \mathrm{~h}$ and the solvent was evaporated. The residue was purified by silica gel chromatography, eluted with $6: 4(\mathrm{v} / \mathrm{v})$ chloroform/methanol to afford glycolipids (5a and $\mathbf{5 b}$ ) in $60-80 \%$ yield. The ratios of trans- to cis-isomers for $\mathbf{5 a}$ and $\mathbf{5 b}$ were 20:1 and 3:1, respectively, as judged from the area of signals corresponding to oxime protons [trans-isomer: $\delta$ $7.73(\mathrm{~d}, J=5.65 \mathrm{~Hz})$; cis-isomer: $\delta 6.98(\mathrm{~d}, J=$ $5.00 \mathrm{~Hz}$ )] in the NMR spectra in a mixed solvent of $\mathrm{CDCl}_{3}$ and $\mathrm{CD}_{3} \mathrm{OD}$.

$N, O-(10,12-P e n t a c o s a d i y n o y l)-N-(\alpha-D-m a n n o p e n-$ tapyranosyl)hydroxylamine 5a. ${ }^{1} \mathrm{H} \mathrm{NMR}\left(\mathrm{CD}_{3} \mathrm{OD} /\right.$ $\left.\mathrm{CDCl}_{3}=1: 1\right)$ : [trans-isomer: $\delta 7.73(\mathrm{~d}, J=7.55 \mathrm{~Hz})$; cis-isomer: $\delta 7.00$ (brs)], 7.62 (d, $5.13(1 \mathrm{H}, \mathrm{H}-1)$, $5.11(1 \mathrm{H}, \mathrm{H}-1), 4.85(1 \mathrm{H}, \mathrm{H}-1), 4.79(1 \mathrm{H}, \mathrm{H}-1), 2.25$ $(\mathrm{t}, 3 \mathrm{H}, J=6.05,6.60 \mathrm{~Hz}), 0.89\left(\mathrm{t}, 3 \mathrm{H}, \mathrm{CH}_{3}\right) . \mathrm{TOF}$ MS $m / z$ 1267.57 $[\mathrm{M}+\mathrm{Na}]^{+}$(Calcd. for $\mathrm{C}_{58} \mathrm{H}_{97} \mathrm{~N}_{3-}$ 
$\mathrm{O}_{25} \mathrm{Na}^{+}:$1266.61).

$\mathrm{N}, \mathrm{O}-(10,12-P e n t a c o s a d i y n o y l)-N$-( sialyl lewis $\mathrm{X})$ hydroxylamine $5 \boldsymbol{b} . \quad{ }^{1} \mathrm{H} \mathrm{NMR}\left(\mathrm{CD}_{3} \mathrm{OD} / \mathrm{CDCl}_{3}=1: 1\right)$ : [trans-isomer: $\delta 7.73(\mathrm{~d}, J=5.65 \mathrm{~Hz})$; cis-isomer: $\delta$ $6.98(\mathrm{~d}, J=5.00 \mathrm{~Hz})], 5.06(\mathrm{~d}, 1 \mathrm{H}, \mathrm{H}-1, J=$ $5.45 \mathrm{~Hz}), 5.02(\mathrm{~d}, 1 \mathrm{H}, \mathrm{H}-1, J=3.5 \mathrm{~Hz}), 4.51(\mathrm{~d}, 1 \mathrm{H}$, $\mathrm{H}-1, J=7.8 \mathrm{~Hz}), 2.83(\mathrm{~d}, 1 \mathrm{H}, J=9.16 \mathrm{~Hz}), 2.25(\mathrm{t}$, $4 \mathrm{H}, J=6.85,6.90 \mathrm{~Hz}), 0.90\left(\mathrm{t}, 3 \mathrm{H}, \mathrm{CH}_{3}\right)$. TOF MS $m / z \quad 1258.13 \quad[\mathrm{M}+\mathrm{Na}]^{+}$(Calcd. for $\mathrm{C}_{58} \mathrm{H}_{97} \mathrm{~N}_{3}-$ $\mathrm{O}_{25} \mathrm{Na}^{+}:$1258.63).

\section{Preparation of Polymerized Liposomes}

Glycolipid 5a $(6.47 \mathrm{mg}, 5.20 \mu \mathrm{mol})$ and 10,12-tricosadiynoyl containing phospholipid $3(41.39 \mathrm{mg}$, $45.2 \mu \mathrm{mol})$ were dissolved in $\mathrm{CHCl}_{3} / \mathrm{MeOH}(9 / 1)$ and the solvent was evaporated to yield a thin lipid film on the inner surface of the flask. Deionized water was added to the flask to adjust the concentration of the lipid to $0.3 \mathrm{mM}$. The aqueous suspension was heated to $70^{\circ} \mathrm{C}$ and sonicated using a probe-type sonicator (Sonifier II, Branson Ultrasonics Corp.) for $10 \mathrm{~min}$. The warm, clear solution containing the liposome was then cooled to $4{ }^{\circ} \mathrm{C}$ and poured into a quartz cell. The solution was irradiated using a UV lamp $(254 \mathrm{~nm}, 8 \mathrm{~W}, 100 \mathrm{~V})$ under an argon atmosphere. The distance of the lamp from the reaction cell was $10 \mathrm{~cm}$.

\section{SEM Observation of Photopolymerized Liposomes}

The morphological features of the fully photopolymerized liposomes $(\mathbf{5 a} / \mathbf{3})$ were examined by Scanning Electron Microscope (SEM). The liposome solution in water was placed on aluminum foil and then desicated using vacuum drying, and the residue was coated with $\mathrm{Pt} / \mathrm{Pb}$ (300 $\AA$ in thickness) with an E102 Hitachi Ion Sputter. SEM pictures were taken using an S-2250N Hitachi Scanning Electron Microscope, $15-25 \mathrm{kV} / 90-120 \mathrm{~mA}$.

\section{Fluorescence Sensing of the Binding of Lectins onto Nanoparticles}

Six samples of the solution $(2.5 \mathrm{~mL})$ of polymerized liposomes in $10 \mathrm{mM}$ Tris buffer $(\mathrm{pH}$ 7.6) were prepared in quartz cells. Concentrated lectin $(1 \mathrm{mg} /$ $100 \mu \mathrm{L}$ ) was added to each cell to be the desired concentrations. After equilibrium for $10 \mathrm{~min}$ at $25^{\circ} \mathrm{C}$, the fluorescence spectrum of each sample from 400 to $700 \mathrm{~nm}$ was recorded by excitation at $380 \mathrm{~nm}$.

\section{RESULTS AND DISCUSSION}

\section{Synthesis of Photopolymerizable Glycolipids}

We previously reported the synthetic route to diacetylene-containing glycolipids. ${ }^{6}$ Using a similar synthetic route, lactose-appending lipid $\mathbf{4}$ was synthe- sized from L-serine (Scheme 2). A glycosylation of $\mathbf{8}$ proceeded smoothly to give $\mathbf{1 0}$ in $95 \%$ yield when an imine-type protection using $\mathrm{N}$-diphenylmethyleneamine was employed. However, Boc-protection of the amino group of $\mathbf{7}$ generated only trace amounts of glycosylated compounds, indicating nucleophilicity of the $\mathrm{OH}$ group was reduced by hydrogen-bonding with the hydrogen on the amine. When the structure of the sugar moiety is more complicated, the synthesis of sugar moieties using stepwise protection-deprotection chemistry is a time-consuming process. Thus, we chose the synthetic strategy using a chemical ligation between free sugars and hydroxylamine-attached lipids. The specific feature of free carbohydrates is the hemiacetal terminus, which can readily react with hydroxylamine groups to form a stable oxime linkage. ${ }^{7,8}$ For the effective displaying of a variety of sugars on the surface of the nanoparticles, diacetylene-containing glycolipids were synthesized by single-step coupling with free carbohydrates as shown in Scheme 3. The coupling of lipid $\mathbf{5}$ and relatively large oligosaccharide molecules, such as mannopentaose and sialyl Lewis $X$, proceeded smoothly in methanol to give new glycolipids $\mathbf{5 a}$ and $\mathbf{5 b}$ in good yield. Although NMR spectroscopy shows that this method generated a mixture of cis- and trans-isomers in the oxime bond, it nevertheless has the great advantage of simplicity in that unprotected sugars can be used.

\section{Preparation of Photopolymerized Glyconanoparticles}

According to a conventional method of vesicle preparation, a suspension of a mixture of lipid $\mathbf{3}$ and glycolipid $(1 / 9 \mathrm{~mol} / \mathrm{mol})$ in pure water was heated to $70^{\circ} \mathrm{C}$ and sonicated (see experimental section). The diacetylene group was polymerized by UV irradiation at $254 \mathrm{~nm}$ under an argon atmosphere, and then the color of the vesicular solution turned pale yellow. The fluorescence intensity increased with UV irradiation and became nearly saturated after $1 \mathrm{~h}$, generating spectra with a maximum fluorescence at $460 \mathrm{~nm}$ upon excitation at $380 \mathrm{~nm}$. The polymerized vesicles were visualized by scanning electron microscope (SEM), which showed that the vesicles formed nanoparticles with a diameter of around $250 \mathrm{~nm}$ (Figure 2).

\section{Fluorescent Detection of the Binding of Lectin onto Glyconanoparticles}

Binding of RCA120, which has four binding sites for lactose, was tested using lactose-displayed nanoparticles that were synthesized by photopolymerization of 3 and $4(4 / 3=1 / 9 \mathrm{~mol} / \mathrm{mol})$. The change in fluorescence was recorded upon the addition of RCA120 in Tris buffer (pH 7.4, $10 \mathrm{mM})$. Fluorescence intensity decreased with the increase in the lectin concentration (Figure 3a). Significantly, there was no 
<smiles>CCCCCCCCNC(=O)C(CO)NC(=O)OCc1ccccc1</smiles>

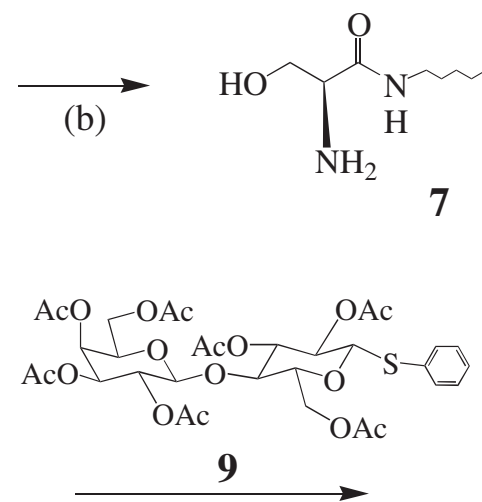

(d)

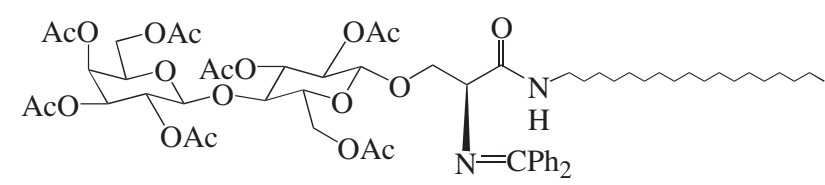

10

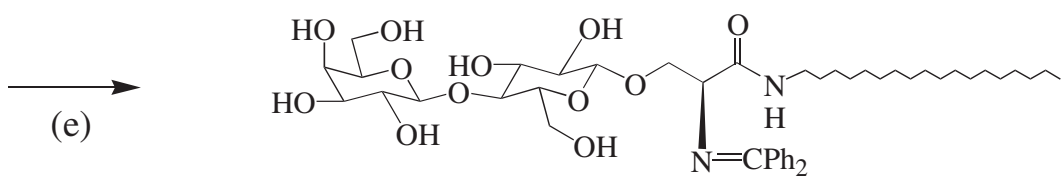

(f)

\section{1}

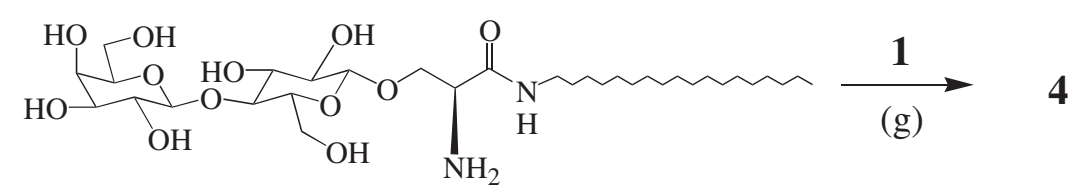

12

Scheme 2. Chemical synthesis of glycolipid 4.

(a) EEDQ, benzene, EtOH, $25^{\circ} \mathrm{C}, 48$ h. (b) $\mathrm{Pd}-\mathrm{C}, \mathrm{H}_{2}, 0.32 \mathrm{MPa}, \mathrm{CH}_{3} \mathrm{OH}, \mathrm{CHCl}_{3}, 25^{\circ} \mathrm{C}, 45 \mathrm{~h}$. (c) Benzophenone imine, $\mathrm{CH}_{2} \mathrm{Cl}_{2}, 25^{\circ} \mathrm{C}$, $40 \mathrm{~h}$. (d) Trifluoromethanesulfonic acid, $\mathrm{N}$-iodosuccinimide, molecular sieves $4 \AA \mathrm{CH}_{2} \mathrm{Cl}_{2}, 25^{\circ} \mathrm{C}$, $15 \mathrm{~h}$. (e) Sodium methoxide, $\mathrm{CH}_{3} \mathrm{OH}$, $25^{\circ} \mathrm{C}$, 4 h. (f) $\mathrm{Pd}-\mathrm{C}, \mathrm{H}_{2}, \mathrm{CH}_{3} \mathrm{OH}, \mathrm{CHCl}_{3}, 25^{\circ} \mathrm{C}, 15 \mathrm{~h}$. (g) $\mathrm{N}$-Ethyldiisopropylamine, 1-ethyl-3-(3-dimethylaminopropyl) carbodiimide, $\mathrm{CH}_{3} \mathrm{OH}, \mathrm{CHCl}_{3}, 25^{\circ} \mathrm{C}, 18 \mathrm{~h}$.

change in UV spectra upon the addition of the proteins, showing that there was no aggregation and/or precipitation of the protein-nanoparticle complex by bridging the nanoparticles. As a control experiment, when concanavalinA (ConA), which has a specific affinity to mannose, was added to the solution of lactose-displayed nanoparticle, no change in fluorescence intensity was observed (Figure 3b). In addition, when RCA120 was added to the solution of nanoparticles prepared only from the matrix lipid $\mathbf{3}$, no change in fluorescence intensity was observed (Figure 3c). These two control experiments clearly indicate that the fluorescent change in Figure $3 \mathrm{a}$ is based on the specific interaction between RCA120 and lactose res- idues. The concentration-dependency is summarized in Figure 3d. We attempted similar experiments using carboxylic acid-type $\mathbf{1}$ or neutral-type $\mathbf{2}$ as the matrix lipid of glyconanoparticles instead of $\mathbf{3}$; however, not negligible change in fluorescence by non-specific binding was observed. This suggests that the use of a phosphatidylcholine-type matrix is of key importance in gaining the signals due to specific recognitions.

Binding of E-selectin, which has a single binding site for the tetrasaccharide sialyl-Lewis $\mathrm{X}\left(\mathrm{sLe}^{\mathrm{X}}\right)$, was tested using the $\mathrm{sLe}^{\mathrm{X}}$-displayed nanoparticle. Eselectin is a vascular cell surface protein which mediates leukocyte rolling on the blood vessel wall and is 

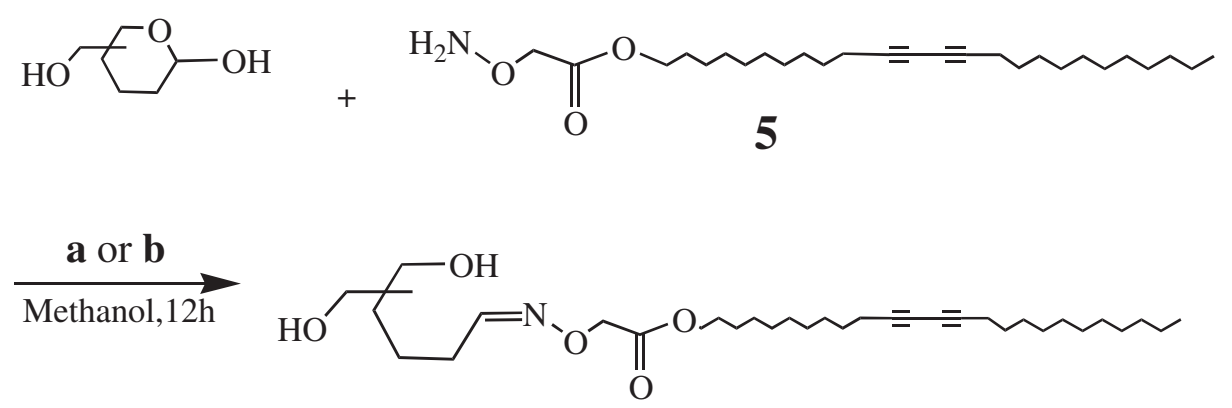

$\mathbf{5 a}$ or $\mathbf{5 b}$

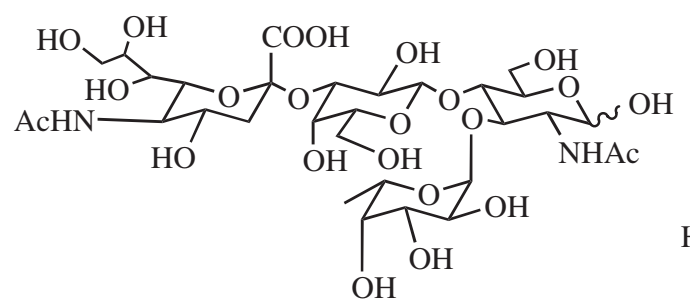

a

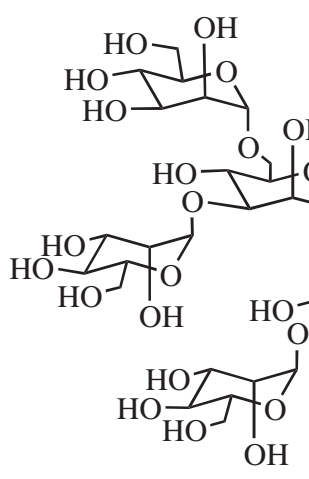

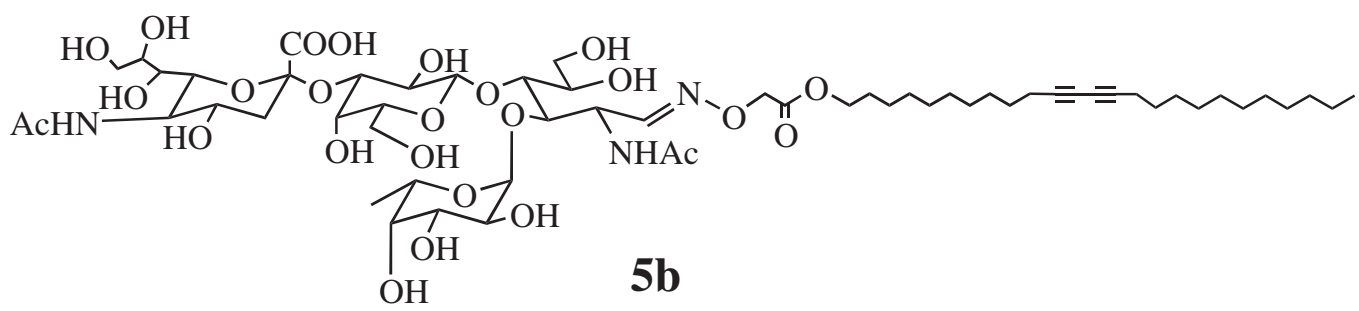

Scheme 3. Chemical ligation between free carbohydrates and hydroxylamine-attached lipid 5. responsible for an early stage of inflammatory response. ${ }^{9}$ Thus, the sensing system of E-selectin binding to $\mathrm{sLe}^{\mathrm{X}}$ would be useful in evaluating the inhibitory effects of new blockers against E-selectin. The fluorescence of the solution of $\mathrm{SLe}^{\mathrm{X}}$-displayed nanoparticles also decreased with the increase in E-selectin concentration, whereas no change in fluorescent intensity was induced for the control nanoparticles that were synthesized from the matrix lipid alone (Figure $4 a$ and $4 b$ ).

For the binding of concanavalinA (ConA), a lectin with a high affinity for mannose, similar results with fluorescent changes were obtained. When a lectin solution was added to the mannopentaose-displayed nanoparticles, the fluorescence intensity decreased depending upon the lectin concentration (Figure $4 \mathrm{c}$ and 4d). The control nanoparticles constructed using the matrix lipid $\mathbf{3}$ alone induced no change in fluorescence upon the addition of ConA, indicating there was no non-specific adsorption. In this case also, there was no change in UV spectra upon the addition of ConA at an $\mathrm{nM}$ range. 


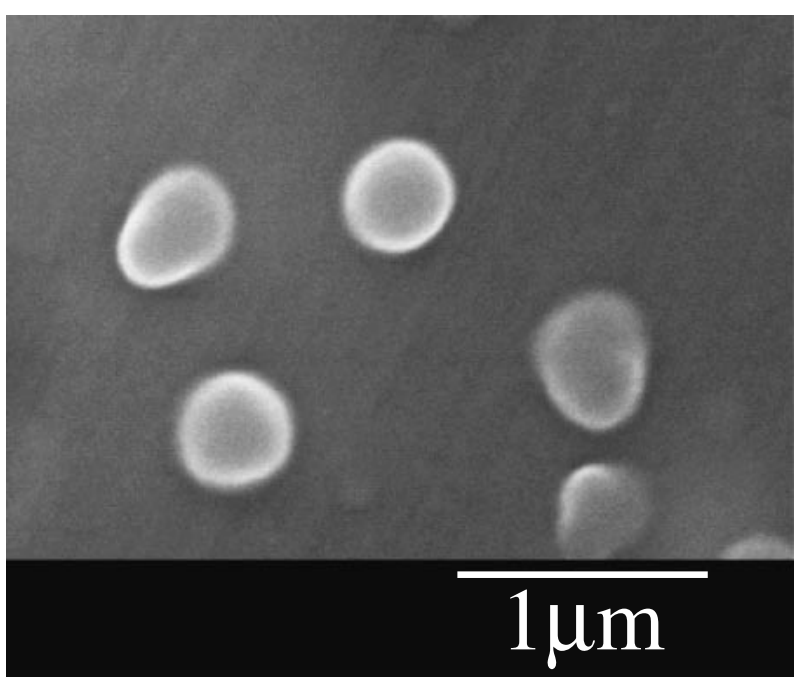

Figure 2. SEM image of the polymerized glyconanoparticles.
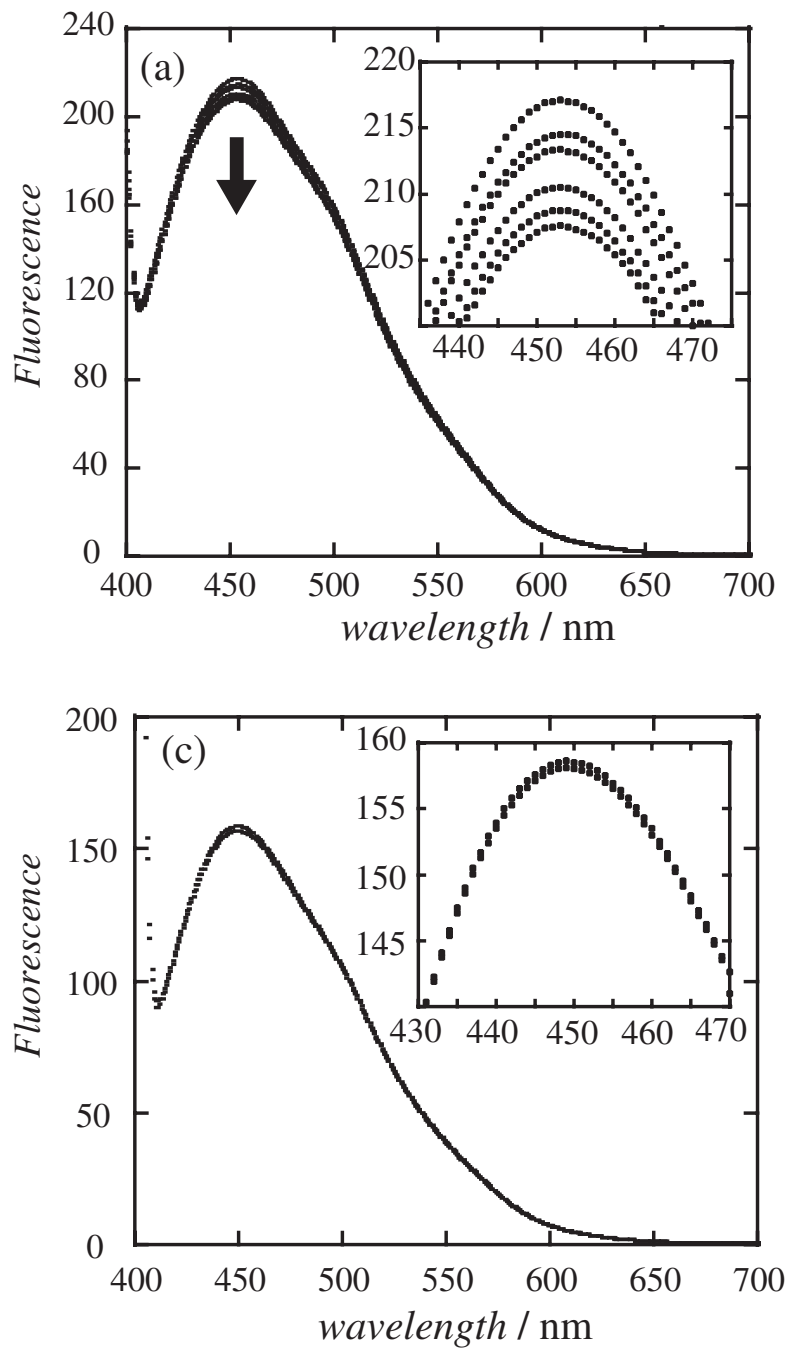

The reason for the quenching of fluorescence upon protein binding is not clear at this stage. Since the coloriometric change upon the binding of toxins seems to be caused by the reorientation of lipids and a reduction in the length of the conjugated lipid backbone due to distribution of the polymer network..$^{10}$ The reason for the change in fluorescence can be similarly speculated. Therefore, we consider that a reduction in the flexibility of the conjugated lipid backbone after the binding of proteins on the surface of the nanoparticles may lead to a decrease in fluorescence.

To prove our speculation, we modulated the UV-irradiation period to control the degree of cross-linkage in the membrane consisting of the lactose lipid $\mathbf{4}$ and matrix lipid 3. When the irradiation period was shortened from 90 to $5 \mathrm{~min}$, the fluorescent response upon the binding of RCA120 was increased [compare Fig-
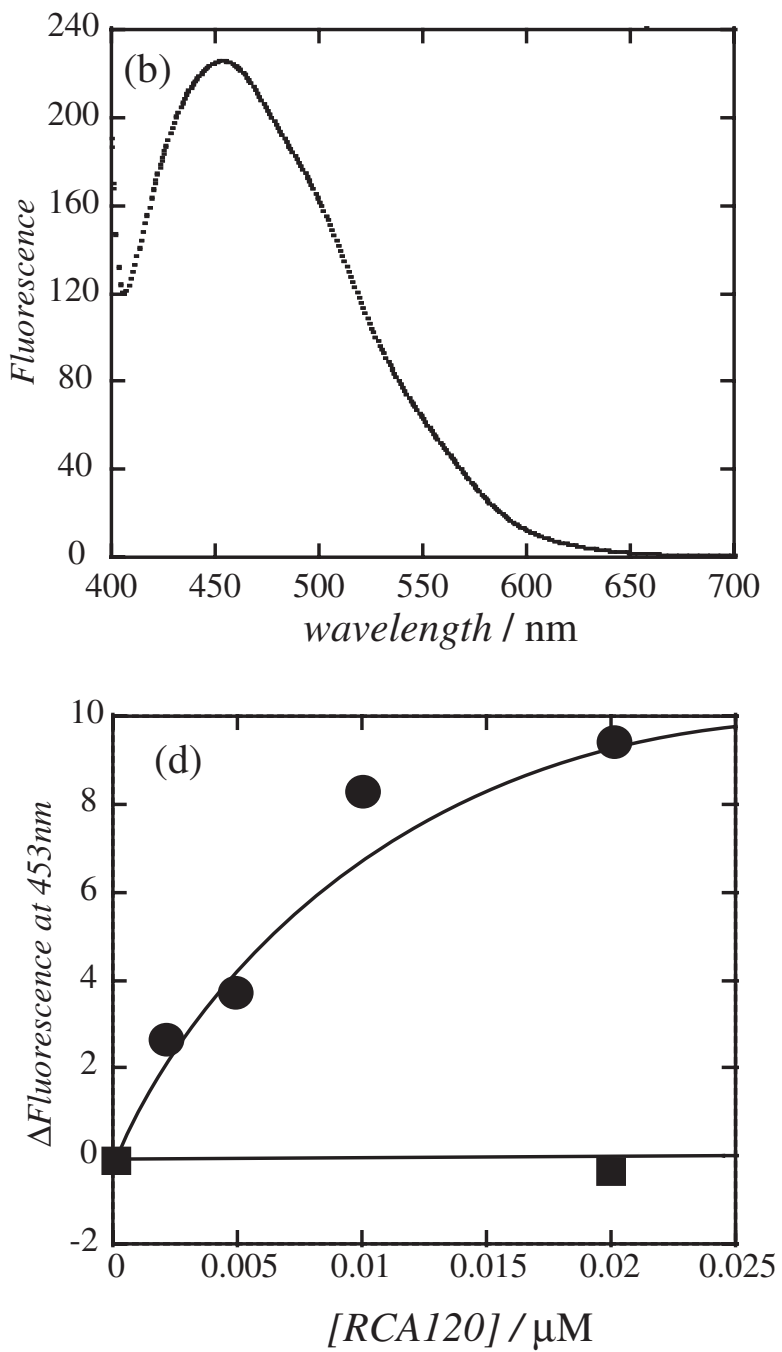

Figure 3. Fluorescent detection of RCA120 using nanoparticle.

(a) Change in fluorescent spectra upon the addition of RCA120 $(0,0.002,0.005,0.01,0.015,0.02 \mu \mathrm{M}$ from top to bottom) to polymerized nanoparticle $(\mathbf{4} / \mathbf{3})$ in Tris buffer $(10 \mathrm{mM}, \mathrm{pH} 7.4)$. (b) Change in fluorescent spectra upon the addition of ConA $(0,0.2 \mu \mathrm{M}$ from top to bottom) to nanoparticle $(\mathbf{4} / \mathbf{3})$ in Tris buffer $(10 \mathrm{mM}, \mathrm{pH} 7.4)$. (c) Change in fluorescent spectra upon the addition of RCA120 (0 and $0.2 \mu \mathrm{M})$ to nanoparticle (3 alone) in Tris buffer (10 mM, pH 7.4). (d) Change in fluorescence as a function of lectin concentrations for figure (a): (closed circle) and figure (b): (closed square). 

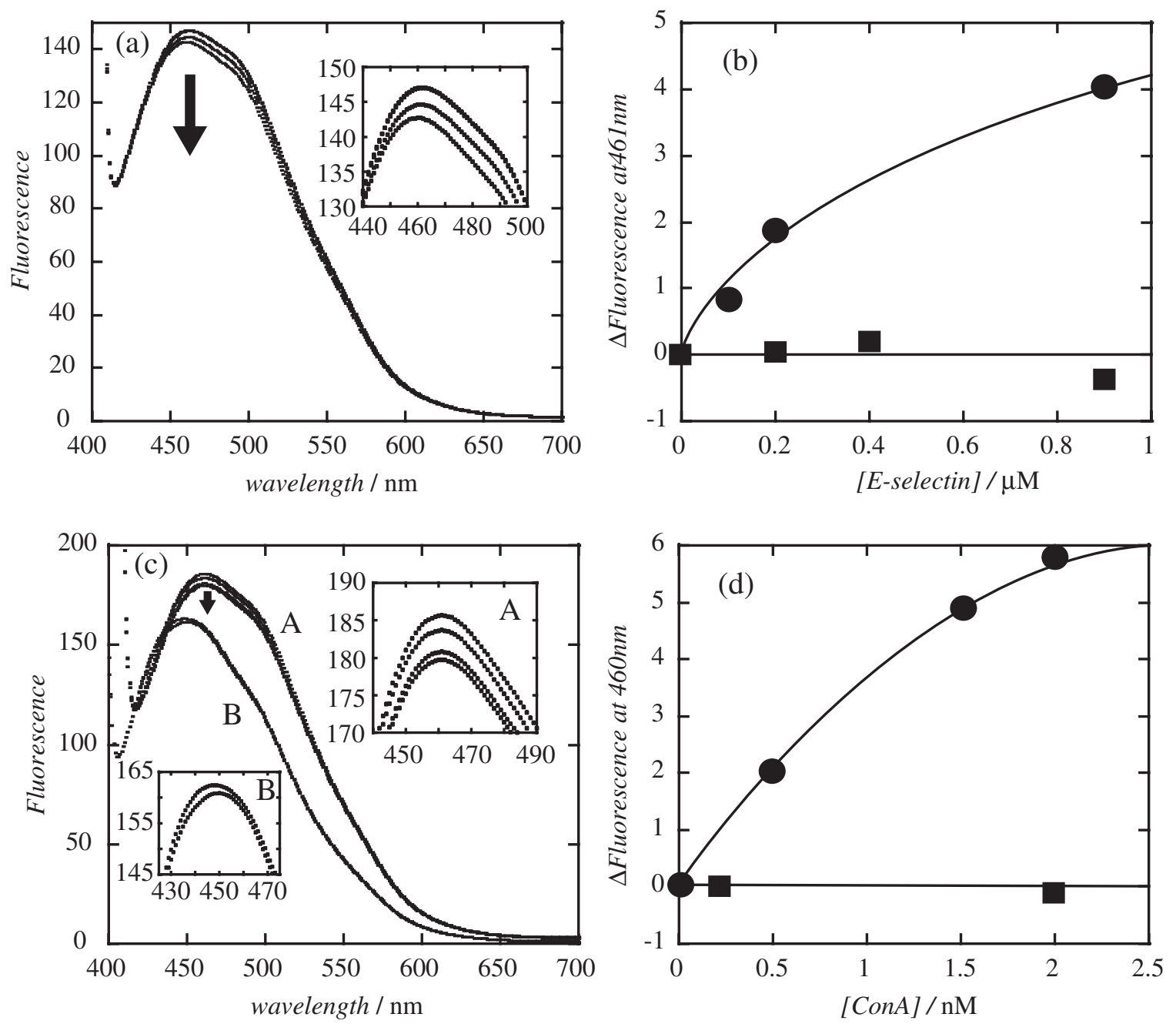

Figure 4. Fluorecent detection of E-selectin and ConA using glyconanoparticles.

(a) Change in fluorescent spectra upon the addition of E-selectin $(0,0.2,0.9 \mu \mathrm{M}$ from top to bottom) to polymerized nanoparticle (5b/3) in Tris buffer (10 mM, pH 7.4). (b) Change in fluorescence intensity as a function of E-selectin concentration. (closed circle) polymerized nanoparticle of $\mathbf{5 b} \mathbf{b}$. (closed square) polymerized nanoparticle of $\mathbf{3}$ only. (c) A: Change in fluorescent spectra upon the addition of ConA $(0,0.5,1.5,2 \mathrm{nM}$ from top to bottom) to polymerized nanoparticle $(\mathbf{5 a} / \mathbf{3})$ in acetate buffer $(10 \mathrm{mM}, \mathrm{pH} 5.2)$. B: Change in fluorescent spectra upon the addition of ConA $(0$ and $2 \mathrm{nM})$ to polymerized nanoparticle $(\mathbf{3}$ only). (b) Change in fluorescence as a function of lectin concentration for A (closed circle) and B (closed square).

ure 3a for $90 \mathrm{~min}$ and Figure 5a for $5 \mathrm{~min}$ ]. This data suggests that the enhanced response of the nanoparticles upon binding is due to the greater mobility of the loosely cross-linked diacetylene network. The effect of irradiation period on fluorescent response is summarized in Table I. When the irradiation period was increased to more than $30 \mathrm{~min}$, only a low response (4\%) was observed. This means that the conformation change in the ene-yne backbone of the rigid fully cross-linked membrane cannot be effectively induced during the protein binding.

As another approach to introduce flexibility to the nanoparticles, L- $\alpha$-phosphatidylcholine dioleoyl (DOPC), which has a low phase-transition temperature $\left(T_{\mathrm{c}}=20^{\circ} \mathrm{C}\right)$, was added. The fluorescence spectra after the addition of RCA120 were shown in Figure $5 b$ and the effect of DOPC on the response is summarized in Table II. The fluorescent response of the DOPC-containing nanoparticles is two times larger than that of nanoparticles without DOPC. As the diacetylene-containing lipids are diluted in the nonpolymerizable DOPC liquid phase (binding assay was carried out at $25^{\circ} \mathrm{C}$ ), long-ranged cross-linkage would be inhibited. Therefore, we consider that these nanoparticles have great flexibility due to the loose cross-linkage, resulting in extensive conformation change upon surface protein binding.

We next directed our attention to the monitoring of enzymatic reactions occurring on the surface of the nanoparticles. We monitored the reaction of hydrolysis of manno-oligosaccharides on the nanoparticles catalyzed by mannosidase (Jack Bean, Seikagaku Corporation) in acetate buffer (Figure 6). When mannosidase was added to a suspension of the mannopen- 


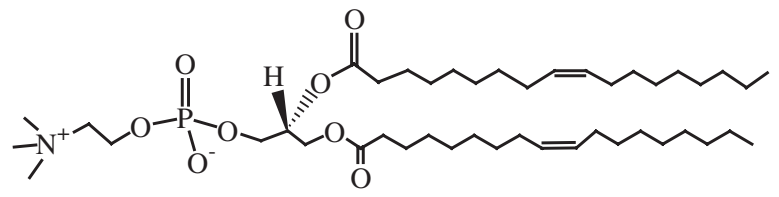

\section{DOPC}
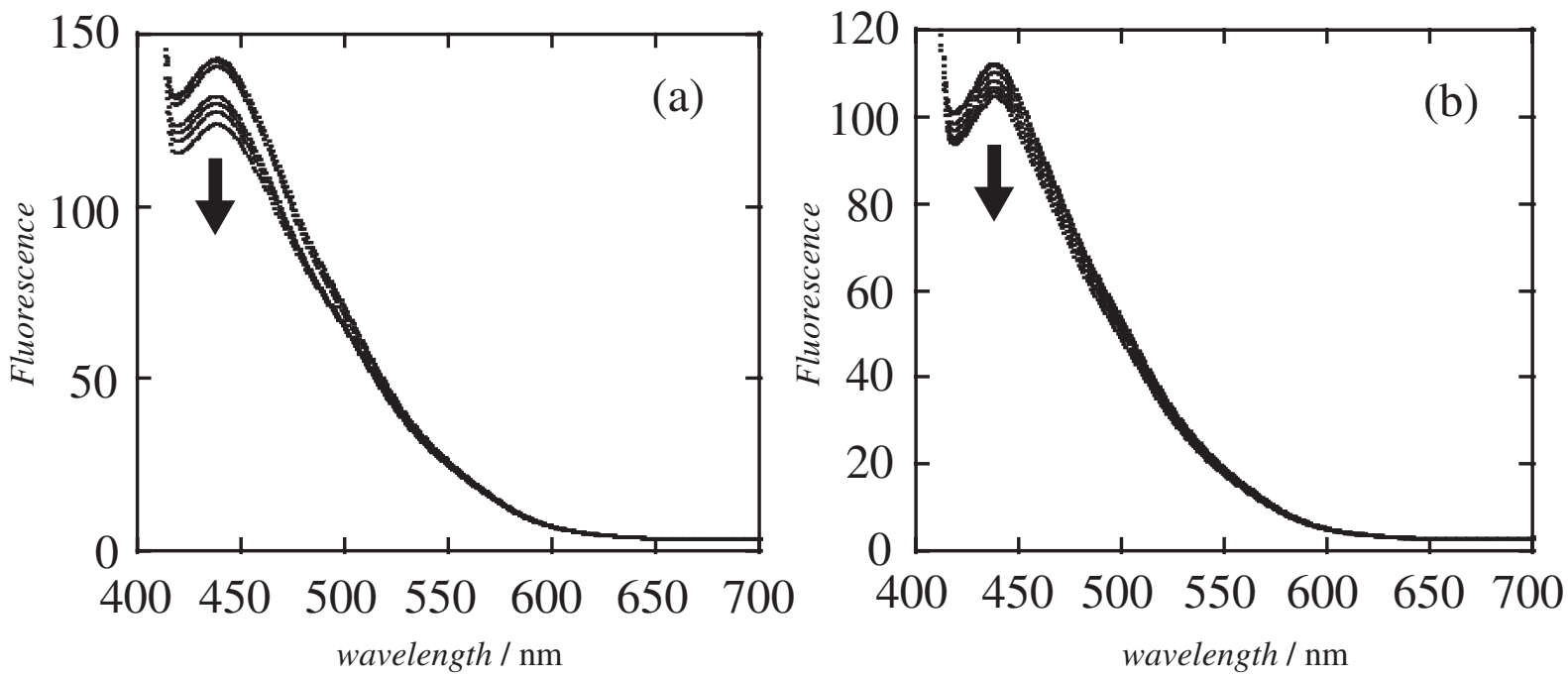

Figure 5. Fluorescent detection of RCA120 using nanoparticles.

(a) Nanoparticle that was prepared by UV irradiation for 5 min. (b) DOPC-containing nanoparticle (3:4:DOPC=80:10:10 mol ratio). [RCA120] $=0$ to $20 \mathrm{nM}$ from top to bottom.

Table I. Effect of UV irradiation period on the fluorescence response after the addition of RCA $120(20 \mathrm{nM})$ to the nanoparticles $(\mathbf{3} / \mathbf{4})$

\begin{tabular}{cc}
\hline $\begin{array}{c}\text { UV irradiation } \\
\text { time (min) }\end{array}$ & $\begin{array}{c}\text { Fluorescence response } \\
(\%)\end{array}$ \\
\hline 1 & 8.5 \\
5 & 12.9 \\
30 & 4.0 \\
90 & 4.4 \\
\hline
\end{tabular}

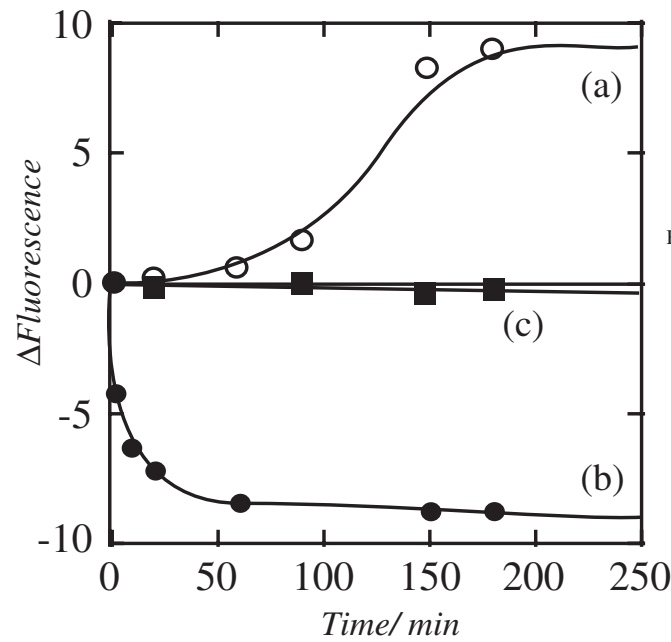

Table II. Effect of DOPC on the fluorescence response after the addition of RCA $120(20 \mathrm{nM})$ to the nanoparticles $(\mathbf{3} / \mathbf{4})$

\begin{tabular}{cccc}
\hline \multicolumn{3}{c}{ Molecular ratio of } \\
the nanoparticles (\%) & Fluorescence response \\
$\mathbf{4}$ & $\mathbf{3}$ & DOPC & $(\%)$ \\
\hline 10 & 90 & 0 & 4.4 \\
10 & 80 & 10 & 3.0 \\
10 & 40 & 50 & 4.2 \\
10 & 10 & 80 & 6.8 \\
\hline
\end{tabular}

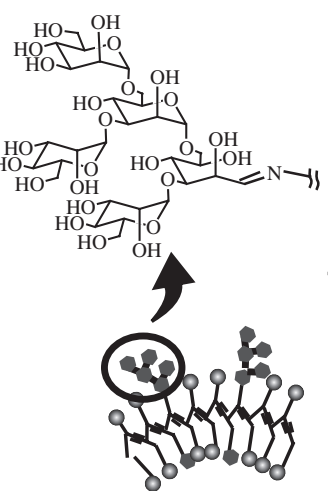

(a) Mannosidase Acetate buffer (10mM,pH 5.2)

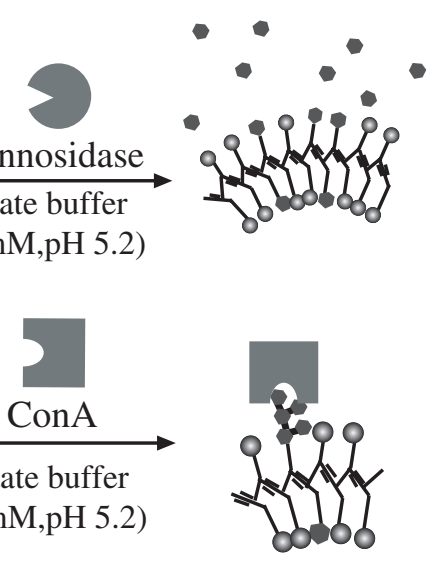

(b)

Figure 6. Timecourse of fluorescence intensities from mannopentaose-displayed nanoparticle. (a) After addition of mannosidase from jack bean to the nanoparticle made of $\mathbf{3 / 4}$. (b) After addition of RCA120 to the same nanoparticle (3/4). (c) After addition of mannosidase to the nanoparticle made of $\mathbf{3}$ alone (control). 
taose-displayed nanoparticles, fluorescence increased with time. When the nanoparticles made of only matrix lipids were used, no response was observed. However, on the addition of lectins, the change in fluorescence was negative. Therefore, change in fluorescence is speculated to result from changes in stress on the diacetylene network, where the stress is increased or decreased with the binding of ConA or released of mannopentaose, resulting in respective negative or positive changes in fluorescence (see Figure 6).

\section{SUMMARY}

The present method employing fluorescent nanoparticles allowed us to detect the binding of protein receptors too small to change common absorption spectra. Using a phosphatidylcholine-type lipid as a matrix in copolymerization reactions, the non-specific binding of proteins was excluded. The fluorescence transition depends on the quantity of proteins titrated into the solutions containing glyconanoparticles. The nanoparticles having great flexibility due to the loose cross-linkage produced large change in fluorescence. Therefore, the conformation change of the polydiacetylenic moiety induced by surface protein binding would cause the fluorescence change. It is demonstrated that the sensing system using the nanoparticles is applicable to monitoring the time-course of enzymatic reactions occurring on the nanoparticle surface. The fluorescent glyconanoparticles will be useful in the construction of sugar-arrays for the detection of unknown lectins and sugar-related enzymes.

Acknowledgment. This work was supported by a grant for the "Glycocluster Research \& Development of Controlling Biomolecules" from NEDO. We thank Ms. Oka for ESI mass measurement at the Center for Instrumental Analysis of Hokkaido University.

\section{REFERENCES}

1. (a) S. Chen, Q. Yu, L. Li, C. L. Boozer, J. Homola, S. S.
Yee, and S. Jiang, J. Am. Chem. Soc., 124, 3395 (2002).

(b) R. J. Green, M. C. Davies, C. J. Roberts, and S. J. B. Tendler, Biomaterials, 20, 385 (1999).

2. (a) H. Matsuno, K. Niikura, and Y. Okahata, Biochemistry, 40, 3615 (2001).

(b) Y. Okahata, K. Niikura, Y. Sugiura, M. Sawada, and T. Morii, Biochemistry, 37, 5666 (1998).

(c) Y. Ebara and Y. Okahata, J. Am. Chem. Soc., 116, 11209 (1994).

(d) T. Sato, T. Serizawa, and Y. Okahata, Biochim. Biophys. Res. Commun., 204, 551 (1994).

3. (a) W. Spevak, J. O. Nagy, D. H. Charych, M. E. Schaefer, J. H. Gilbert, and M. D. Bednarski, J. Am. Chem. Soc., 115, 1146 (1993).

(b) D. H. Charych, Q. Cheng, A. Reichert, G. Kuziemko, M. Stroh, J. O. Nagy, W. Spevak, and R. C. Stevens, Chem. Biol., 3, 113 (1996).

(c) D. H. Charych, J. O. Nagy, W. Spevak, and M. D. Bednarski, Science, 261, 585 (1993).

(d) J. J. Pan and D. H. Charych, Langmuir, 13, 1365 (1997).

(e) A. Berman, D. J. Ahn, A. Lio, M. Salmeron, A. Reichert, and D. H. Charych, Science, 269, 515 (1995).

4. S. Okada, S. Peng, W. Spevak, and D. H. Charych, Acc. Chem. Res., 31, 229 (1998).

5. Z. Ma, J. Li, L. Jiang, J. Cao, and P. Boullanger, Langmuir, 16, 7801 (2000).

6. (a) N. Nagahori, K. Niikura, R. Sadamoto, K. Monde, and S.-I. Nishimura, Aust. J. Chem., 56, 567 (2003).

(b) N. Nagahori, K. Niikura, R. Sadamoto, M. Taniguchi, A. Yamagishi, K. Monde, and S.-I. Nishimura, Adv. Synth. Catal., 345, 729 (2003).

7. (a) S. E. Cervigni, P. Dumy, and M. Mutter, Angew. Chem., Int. Ed., 35, 1230 (1996).

(b) F. Peri, P. Dumy, and M. Mutter, Tetrahedron, 54, 12269 (1998).

8. E. C. Rodriguez, K. A. Winans, D. S. King, and C. R. Bertozzi, J. Am. Chem. Soc., 119, 9905 (1997).

9. (a) G. R. Larsen, D. Sako, T. J. Ahern, M. Shaffer, J. Erban, S. A. Sajer, R. M. Gibson, D. D. Wagner, B. C. Furie, and B. Furie, J. Biol. Chem., 267, 11104 (1992).

(b) K. Ley, M. Allietta, D. C. Bullard, and S. Morgan, Circ. Res., 83, 287 (1998).

10. Q. Huo, K. C. Russell, and R. M. Leblanc, Langmuir, 15, 3970 (1999). 